\title{
Integrated nutrition management in pigeon pea intercropping systems for enhancing production and productivity in sustainable manner- $A$ review
}

\author{
Narendra Kumawat ${ }^{1 *}$, Rakesh Kumar ${ }^{2}$, Jagdeesh Morya ${ }^{3}$, I.S. Tomar ${ }^{1}$ and R.S. Meena ${ }^{4}$, \\ ${ }^{1}$ Zonal Agricultural Research Station, Jhabua 457661 (MP) INDIA \\ ${ }^{2}$ Division of Crop Research, ICAR RC for Eastern Region Patna -800014 (Bihar), INDIA \\ ${ }^{3}$ Krishi Vigyan Kendra, Jhabua 457661 (MP), INDIA \\ ${ }^{4}$ Agricultural Research Station, Sriganganagar, SKRAU, Bikaner (Rajasthan), INDIA \\ *Corresponding author. E-mail: kumawatandy@gmail.com
}

Received: January 31, 2017; Revised received: May 1, 2017; Accepted: October 3, 2017

\begin{abstract}
India is the largest producer and consumer of pulses in the world accounting for about 29 per cent of the world area and 19 per cent of the world's production. In order to achieve self-sufficiency in pulses, the projected requirement by the year 2025 is estimated at $27.5 \mathrm{MT}$. To meet this requirement, the productivity needs to be enhanced to $1000 \mathrm{~kg} / \mathrm{ha}$, and an additional area of about 3-4 Mha has to be brought under pulses besides reducing post-harvest losses. This uphill task has to be accomplished under more severe production constraints, especially abiotic stresses, abrupt climatic changes, emergence of new species/ strains of insect-pests and diseases, and increasing deficiency of secondary and micronutrients in the soil. This requires a two-pronged proactive strategy, i.e. improving per unit productivity and reducing cost of production. The yield levels of pulses have remained low and stagnant, also area and total production. Among the pulses pigeon pea is second most important grain-legumes and major constraints in pigeon pea production is mostly grown in grown on marginal lands under rainfed agriculture and without nutrient management, hence are prone to abiotic stresses. Therefore it is essential for higher production and productivity of pigeon pea, use of high yielding varieties which suitable for intercrop as well as sole cropping system with best nutrient management practices.
\end{abstract}

Keywords: Intercrop, Nutrient management practices, Pigeon pea, Productivity

\section{INTRODUCTION}

India being the largest producer 17.35 MT and processor of pulses in the world also imports $4.58 \mathrm{MT}$ annually on an average to meet its ever increasing consumption needs of 22 MT. According to Indian Institute of Pulses Research's Vision document, India's population is expected to touch 1.68 billion by 2030 and the pulse requirement for the year 2030 is projected at 32 million tons with anticipated required annual growth rate of $4.2 \%$. Among the pulses pigeon pea (Cajanus cajan (L.) Millsp.) is the second most important kharif grain legume after chickpea in India grown predominantly under rainfed conditions. It occupies an area of about $3.90 \mathrm{~m}$ ha with a total production of $3.17 \mathrm{MT}$ with an average productivity of $813 \mathrm{~kg} / \mathrm{ha}$ (Tiwari, 2016). Pigeon pea is a popular pulse crop with Indian farmers especially in view of their suitability under dryland conditions and their adoptability for pure as well as mixed/intercropping system. The low yield of pigeon pea is not only due to its cultivation on sub-marginal lands, but also because of inadequate and imbalance fertilization as well as continuous use of inorganic fertilizers which decreased the productivity, sustainability, soil health and finally affecting environment (Singh, 2007). Intensive agriculture using exhaustive high yielding varieties of crops had led to heavy withdrawal of nutrients from the soil during past few years and fertilizer consumption remained much below in comparison to removal in India. This gap between nutrient removal and supply cannot be bridged by fertilizer alone. It can only be achieved by integrated nutrient approach. To avoid negative environmental effects by fertilizer application, eco-friendly management practices can be adopted at farm level. These practices include efficient recycling of nutrients involving crop residues and waste products on the farm and proper adjustment of fertilizer doses according to requirement. Development and application of such a system appears to be an alternative to maintain sustainable agricultural system (Dijk and Pal, 1995). Adequate manuring not only improves the crop yield but also sustains the soil health and productivity. Moreover, chemical fertilizers are becoming costlier input in agriculture. Therefore, it is right time to evaluate the feasibility and efficiency of organic waste not only for improving and build up of soil fertility but also to increase efficiency of chemical fertilizer. 
Integration of chemical fertilizer with organic manures has been found to be quite promising not only in maintaining higher productivity but also in greater stability to crop production. Therefore, integration of inorganic, organic and biofertilizers are essential in realizing the higher yield and reducing cost of cultivation of pigeon pea. The work of many researchers done and discussed here in respect to integrated nutrient management practice may play significant role in enhancing production and productivity of pigeon pea in a sustainable manner as well as soil health.

Effect of integrated nutrient management on growth characters

Generally fertilizers are applied to a crop cultivar with a view to realize maximum yields within its potential. Like other field crops, pigeon pea also requires essential elements viz., nitrogen, phosphors, potassium, sulphur and zinc with the integration of organic manures and biofertilizers just to provide balanced nutrient and enhancing the productivity and profitability of crop.

Kene et al. (1990) at Nagpur reported that application of $37.5 \mathrm{~kg} \mathrm{~N}+75 \mathrm{~kg} \mathrm{P}_{2} \mathrm{O}_{5}+20 \mathrm{~kg} \mathrm{~K} 2 \mathrm{O}+10 \mathrm{~kg}$ $\mathrm{ZnSO}_{4} /$ ha significantly increased the nodules/plant and $\mathrm{N}$ concentration in nodules of pigeon pea over no application or (control). Gupta and Rathore (1995) observed that growth attributes (plant height and dry matter/plant) significantly increased with the application of full recommended dose of fertilizer to both the component crops in pigeon pea + sesame intercropping system over the lower doses of recommended dose. Namedo and Gupta (1999) found that application of $100 \% \mathrm{RDF}(20 \mathrm{~kg} \mathrm{~N}$ and $50 \mathrm{~kg}$ $\mathrm{P}_{2} \mathrm{O}_{5} /$ ha) and seed inoculation with Rhizobium and PSB gave the higher number of nodules/plant, dry weight of nodules/plant and shoot dry weight (g/plant) of pigeon pea over the $100 \%$ RDF alone and other treatments. In an experiment conducted at New Dehli, it was reported that application of fertilizer up to 75 per cent recommended dose $\left(18 \mathrm{~N}+46 \mathrm{P}_{2} \mathrm{O}_{5}+20 \mathrm{~K}_{2} \mathrm{O}\right.$ $\mathrm{kg} / \mathrm{ha}$ ) significantly enhanced the growth parameters viz., plant height, branches/plant and LAI of pigeon pea over control (Shivran et al., 2000). Similarly, Saxena et al. (2001) recorded significant increase in growth parameters viz., plant height, leaf area index (LAI), dry matter accumulation, crop growth rate (CGR), relative growth rate (RGR) and net assimilation rate (NAR) of soybean with application of $20 \mathrm{~kg} \mathrm{~N}+$ $60 \mathrm{~kg} \mathrm{P}_{2} \mathrm{O}_{5}+40 \mathrm{~K}_{2} \mathrm{O} \mathrm{kg} / \mathrm{ha}$ over control. Singh and Pal (2003) observed that application 100\% RDF significantly increased the plant height, dry matter production and leaf area index of pigeon pea in comparison to $50 \% \mathrm{RDF}$ and control. In a three year field experiment at Kanpur (UP) on pigeon pea, Verma et al. (2004) stated that application of zinc (foliar spray of $\left.0.5 \% \mathrm{ZnSO}_{4}\right)$ significantly increased the plant height, number of leaves and branches/plant of pigeon pea over seed soaking $\left(0.5 \% \mathrm{ZnSO}_{4}\right)$ and seed soaking $\left(0.5 \% \mathrm{ZnSO}_{4}+\right.$ foliar spray) treatments. Ramesh et al. (2006) conducted a field experiment on growth of pigeon pea as influenced by different treatments of organic manures (cattle dung@4t/ha, vermicompost (a) $3 \mathrm{t} / \mathrm{ha}$ and poultry manure @ $2 \mathrm{t} / \mathrm{ha}$ ) and found that among organic sources, cattle dung recorded the maximum crop growth in terms of plant height, number of branches/plant and biomass accumulation, vermicompost remained intermediate while poultry manure recorded the lowest values of above parameters but was superior to control.

Patil and Padmani (2007a) while working on pigeon pea at Junagadh (Gujarat) observed that application of $100 \%$ RDF $\left(25 \mathrm{~N}+50 \mathrm{P}_{2} \mathrm{O}_{5}+\mathrm{K}_{2} \mathrm{O} 0.0 \mathrm{~kg} / \mathrm{ha}\right)$ significantly increased the plant height, branches/plant and number of nodules/plant over $50 \%$ RDF and control, however it was at par with $75 \%$ RDF. Singh (2007) conducted a field experiment at BHU, Varanasi and found that significantly increased plant height, number of branches and dry matter/plant of pigeon pea with the application of $50 \% \mathrm{RDF}+5 \mathrm{t} \mathrm{FYM/ha} \mathrm{which}$ was remained at par with $10 \mathrm{t} \mathrm{FYM} \mathrm{and} 100 \%$ RDF. Singh and Singh (2012) results revealed that the application of phosphorus $75 \mathrm{~kg} \mathrm{ha}^{-1}$ gave the higher plant height, branches/plant, dry matter production/ plant, chlorophyll content (SPAD), leaf area and LAI which were significantly superior over $25 \mathrm{~kg} \mathrm{P}_{2} \mathrm{O}_{5} /$ ha and control but remained at par with $50 \mathrm{~kg} \mathrm{P}_{2} \mathrm{O}_{5} /$ ha during both the years. A field experiment was carried out by Saritha et al. (2012) reported that application of 150\% RDF + vermicompost @ 1 t/ha produced higher plant height, no. of branches/plant leaf area, leaf area index (LAI), dry matter production/plant as compared to $200 \% \mathrm{RDF}+$ vermicompost @ 2 t/ha). While working on pigeon pea, Kumawat et al. (2013b) carried out a field study on pigeon pea results revealed that application of $100 \% \mathrm{RDF}+50 \% \mathrm{RDN}+5 \mathrm{~kg} \mathrm{Zn} /$ ha significantly increased the plant height $(216.7 \mathrm{~cm})$ and branches/plant (21.6) which was at par with 50\% $\mathrm{RDF}+100 \% \mathrm{RDN}+5 \mathrm{~kg} \mathrm{Zn} / \mathrm{ha}$ and superior to remaining nutrient management treatments. Singh et al. (2014) carried out field experiment at Shamli (UP) results revealed that plant height, no. of branches/plant and dry matter production/plant of pigeon pea were higher significantly recorded with the application of 90 $\mathrm{P}_{2} \mathrm{O}_{5} /$ ha and $40 \mathrm{~S} /$ ha significantly superior over control 30 and $60 \mathrm{~kg} \mathrm{P}_{2} \mathrm{O}_{5}$ and $20 \mathrm{~kg} \mathrm{~S} / \mathrm{ha}$, respectively. Sahay et al. (2015) carried out a field experiment at Varanasi on pigeon pea and reported that application of $100 \%$ $\mathrm{RDF}+5 \mathrm{t} \mathrm{FYM}+$ Rhizobium + PSB gave higher plant height, numbers of branches and dry matter accumulation /plant followed by $50 \%$ RDF +5 t FYM + Rhizobium + PSB.

Rathod et al. (2016) carried out an field experiment at Gulbarga found that application of $\mathrm{RDF}+\mathrm{ZnSO}_{4} @ 15$ $\mathrm{kg} / \mathrm{ha}$ increased the plant height, number of primary 
branches and secondary branches of pigeon pea however, it was on par with $\mathrm{RDF}+\mathrm{ZnSO}_{4} @ 25 \mathrm{~kg} / \mathrm{ha}$ and significantly superior to rest of the treatments. Pal et al. (2016) observed that among the nutrient management practices, application of $100 \%$ recommended dose of fertilizer $+2.5 \mathrm{t}$ vermicompost recorded significantly higher growth characters i.e. plant height, no. of branches, dry matter accumulation/ plant, LAI nodules/plant, dry weight of nodules/plant as compared to rest of the nutriment management practices. Singh et al. (2016a) conducted a field experiment at Ranchi (Jharkhand) reported that among the RDF (recommended dose of fertilizer) levels application of $200 \%$ RDF (30:60:30:30 kg NPKS/ha) gave significantly higher growth characters such as plant height, no. of primary and secondary branches/ plant, LAI, no. of nodules/plant and dry weight of nodules/plant, however it was at par with $150 \% \mathrm{RDF}$ and superior to $100 \%$ RDF.

Effect of integrated nutrient application on yield attributes and yield

Ali (1981) concluded that application of $40 \mathrm{~kg} \mathrm{P}_{2} \mathrm{O}_{5-} /$ ha significantly increased the grain yield of pigeon pea $(9.66 \mathrm{q} / \mathrm{ha})$ over the $20 \mathrm{~kg} \mathrm{P}_{2} \mathrm{O}_{5} /$ ha. Chauhan and Singh (1981) found that application of $80 \mathrm{~kg} \mathrm{P}_{2} \mathrm{O}_{5-} / \mathrm{ha}$ obtained the maximum yield of pigeon pea $(69.5 \%)$ higher than control. Thakur et al. (1988) found that application of $20 \mathrm{~kg} \mathrm{~N}+50 \mathrm{~kg} \mathrm{P}_{2} \mathrm{O}_{5} /$ ha significantly increased the seed yield of pigeon pea (from 1.28 to $1.70 \mathrm{t} / \mathrm{ha}$ ) but further increase the rate of $\mathrm{N}, \mathrm{P}$ rate gave no additional seed yield. Kene et al. (1990) reported that application of $37.5 \mathrm{~kg} \mathrm{~N}+75 \mathrm{~kg} \mathrm{P}_{2} \mathrm{O}_{5}+20 \mathrm{~kg}$ $\mathrm{K}_{2} \mathrm{O}+10 \mathrm{~kg} \mathrm{ZnSO}_{4} /$ ha significantly improve the grain yield of pigeon pea $(861 \mathrm{~kg} / \mathrm{ha})$ over control $(283 \mathrm{~kg} /$ ha). Billore et al. (1993) an experiment was conducted at Sehore (MP) and observed that maximum seed yield highest under application of $100+75 \%(20 \mathrm{~N}+60$ $\mathrm{P}_{2} \mathrm{O}_{5} \mathrm{~kg} / \mathrm{ha}$ ) fertility levels to pigeon pea + soybean intercropping over remaining fertility levels. Padmalatha and Rao (1993) reported that application of $30 \mathrm{~kg}$ $\mathrm{N}+75 \mathrm{~kg} \mathrm{P}_{2} \mathrm{O}_{5}+\mathrm{K}_{2} \mathrm{O} 0.0 \mathrm{~kg} /$ ha significantly increased the dry matter and seed yield of pigeon pea over $20 \mathrm{~kg} \mathrm{~N}+20 \mathrm{~kg} \mathrm{P}_{2} \mathrm{O}_{5}+\mathrm{K}_{2} \mathrm{O} 0.0 \mathrm{~kg} / \mathrm{ha}$. Singh et al. (1994) reported that maximum seed yield of pigeon pea $(1.85 \mathrm{t} / \mathrm{ha})$ with the application of $40 \mathrm{~kg} \mathrm{~N}+80 \mathrm{~kg}$ $\mathrm{P}_{2} \mathrm{O}_{5}+40 \mathrm{~kg} \mathrm{~K} 2 \mathrm{O} /$ ha which also gave highest benefit cost ratio (1.57). Arunachalam et al. (1996) observed that seed yield of pigeon pea was highest with application of $40 \mathrm{~kg} \mathrm{P}_{2} \mathrm{O}_{5}+20 \mathrm{~kg} \mathrm{~K} 2 \mathrm{O} / \mathrm{ha}$. Srinivas and Raju (1997) reported that yield and yield attributing charters viz., number of pods per plant, 100-grain weight and grain yield of pigeon pea significantly increased with

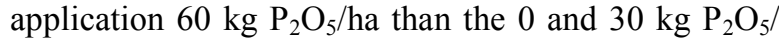
ha. Under rainfed conditions at Morena (M.P.), Yadav et al. (1997) found that pods/plant and test weight significantly superior under pigeon pea + blackgram (100\% RF i.e. $20 \mathrm{~kg} \mathrm{~N}$ and $50 \mathrm{~kg} \mathrm{P}_{2} \mathrm{O}_{5-} / \mathrm{ha}$ ) as com- pared to sole pigeon pea, whereas, seed yield/plant was higher in pure pigeon pea. In a two year investigation at New Dehli on sandy loam soil, application of $100 \%$ recommended dose fertilizer $\left(18 \mathrm{~N}+46 \mathrm{P}_{2} \mathrm{O}_{5}+20 \mathrm{~K}_{2} \mathrm{O} \mathrm{kg} / \mathrm{ha}\right)$ significantly increased pods/plant, seeds/pod and 1000seed weight of pigeon pea during 1997-1998 and 19981999 over control (Shivran and Ahlawat, 2000). Adhikary and Sarkar (2000) reported that pigeon pea + groundnut paired row system at $60 \mathrm{~kg} \mathrm{P}_{2} \mathrm{O}_{5} /$ ha gave the highest pigeon pea seed yield and monetary advantage.

Jat and Ahlawat (2003) reported that higher yield attributes (pods/plant and seeds/pod) and grain yield of pigeon pea and pigeon pea equivalent yield were recorded in pigeon pea+ groundnut intercropping system along with $40 \mathrm{~kg} \quad \mathrm{P}_{2} \mathrm{O}_{5} /$ ha. In another experiment, conducted at Coimbatore (Tamil Nadu) Velayutham et al. (2003) opinion that growing of pigeon pea in paired row with full RDF $(25 \mathrm{~N}+50$ $\left.\mathrm{P}_{2} \mathrm{O}_{5-} \mathrm{kg} / \mathrm{ha}\right)+$ greengram recorded more plant height, number of pods/plant, number of seeds/pod, 100-seed weight and seed yield which was at par with paired row pigeon pea full dose of RDF $\left(20 \mathrm{~N}+50 \mathrm{P}_{2} \mathrm{O}_{5-} \mathrm{kg} /\right.$ ha) + greengram $\left(2.5 \mathrm{~N}+5.0 \mathrm{P}_{2} \mathrm{O}_{5-} \mathrm{kg} / \mathrm{ha}\right)$. Singh and Pal (2003) from New Dehli reported that application of $100 \%$ RDF significantly increased braches/plant, number of pods/branch, pod length, weight/pod, number of grains/pod, weight of grains/pod, 1000grain weight, grain and stalk yield of pigeon pea over $50 \%$ RDF and control. Verma et al. (2004) from Kanpur (UP) reported that application of zinc (foliar spray of $0.5 \% \mathrm{ZnSO}_{4}$ ) significantly increased the number of pods/plant number of seeds/plant, weight of seeds/plant, test weight and seed yield of pigeon pea over other treatments.

Kumar and Kushwaha (2006) observed that pods/plant and seed and stalk yield of pigeon pea significantly improved with application of $80 \mathrm{~kg} \mathrm{P}_{2} \mathrm{O}_{5} /$ ha over (20 and $\left.40 \quad \mathrm{P}_{2} \mathrm{O}_{5} / \mathrm{ha}\right)$, but it was remained at par with $60 \mathrm{~kg} \mathrm{P}_{2} \mathrm{O}_{5} /$ ha. The plant height, seeds/pod and 100 -seed weight did not affected significantly by application of different levels of phosphorus (20, 40 and $80 \quad \mathrm{P}_{2} \mathrm{O}_{5} / \mathrm{ha}$ ). Ramesh et al. (2006) carried out a field experiment at Bhopal, reported that among different sources, chemical fertilizers recorded the higher number of pods/plant in pigeon pea which were at par with cattle dung application. Application of vermicompost, phosphocompost and poultry manure resulted in similar number of pods/plant which were at par with each other but significantly superior to control. Seeds/pod and 100-seed weight did not differ significantly among sources. Seed yield/plant was the highest in chemical fertilizer and the lowest in control. Karwasra and Kumar (2007) in a four year study (2002 -2005) on pigeon pea concluded that $40 \mathrm{~kg} \mathrm{~N}+80 \mathrm{~kg}$ $\mathrm{P}_{2} \mathrm{O}_{5} /$ ha significantly improved grain yield in all the 
four years over control and other lower levels i.e. NPK tried in different combinations. The average increase in

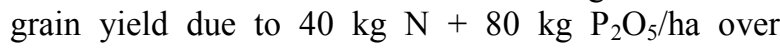
control was $62.5,54.0,89.3$ and 68.2 per cent during 2002, 2003, 2004 and 2005, respectively. An experiment conducted during kharif season on pigeon pea + greengram intercropping under rainfed condition, it was found that application of $40 \mathrm{~kg} \mathrm{P}_{2} \mathrm{O}_{5}+25 \mathrm{~kg} \mathrm{~S}+$ PSB significantly increased the seed and stalk yield of pigeon pea over control, however, it was at par with 40 $\mathrm{kg} \mathrm{P}_{2} \mathrm{O}_{5}+25 \mathrm{~kg} \mathrm{~S} / \mathrm{ha}$ (Kumar and Rana, 2007). Patil and Padmani (2007b) reported that application of $100 \%$ RDF $\left(25 \mathrm{~N}+50 \mathrm{P}_{2} \mathrm{O}_{5}+\mathrm{K}_{2} \mathrm{O} 0.0 \mathrm{~kg} / \mathrm{ha}\right)$ significantly increased the yield and yield attributes viz., number of pods/plant, number of seeds/pod, test weight, grain yield/plant, grain and stover yield of pigeon pea over $50 \% \mathrm{RDF}$ and control, but it was remained at par with $75 \% \mathrm{RDF}$.

Reddy et al. (2007) in a field experiment at Warangal (Andhra Pradesh) concluded that application 100\% RDF $\left(20 \mathrm{~N}+50 \mathrm{P}_{2} \mathrm{O}_{5}+20 \mathrm{~K}_{2} \mathrm{O}+20 \mathrm{~S} \mathrm{~kg} / \mathrm{ha}\right)+30 \mathrm{~kg}$ sodium molybadate to pigeon pea significantly increased pods per plant and seed yield over 100\% RDF and control and other treatments and being at par with each other, however, plant height and 100 seed weight were not influenced significantly by micronutrients along with RDF. Singh (2007) reported that maximum grain yield and stover yield of pigeon pea were observed with the application of 50\% RDF $+5 \mathrm{t} \mathrm{FYM/}$ ha over the other treatments. Ghosh et al. (2009) carried out field experiment of soybean/sorghum intercropping and found that integrated use of organic and inorganic-fertilizer recorded significantly higher soybean equivalent yield (SEY) over control and sole inorganic fertilizer. The highest SEY was recorded with 75\% NPK+4 t FYM/ha.

Deshbhratar et al. (2010) at Nagpur reported that application of $50 \mathrm{~kg} \mathrm{P}_{2} \mathrm{O}_{5} /$ ha (through DAP) and $20 \mathrm{~kg}$ $\mathrm{S} /$ ha (though elemental sulphur) significantly increased the number of pods/plant, number of seeds/ pod, grain, straw yield/plant, and grain, straw yield over control and $25 \mathrm{~kg} \mathrm{P}_{2} \mathrm{O}_{5} /$ ha. Sharma et al. (2010a) revealed that application of $\mathrm{RDF}+15 \mathrm{~kg} \mathrm{ZnSO} / \mathrm{ha}$ significantly higher number of pods/plant, number of seeds/pod, 100-seed weight and seed yield of pigeon pea followed by RDF + $25 \mathrm{~kg} \mathrm{ZnSO} 4$ and $\mathrm{RDF}+$ seed treatment with sodium molybdenum @ $4 \mathrm{~g} / \mathrm{kg}$ as compared to control. Reddy et al. (2011) reported that application of $50 \% \mathrm{RDF}+$ seed treatment with Rhizobium@200 g/kg seeds recorded significantly higher number of branches/plant, pods and higher grain yield of pigeon pea $(16.3,151.3$ and $1358 \mathrm{~kg} / \mathrm{ha}$, respectively) as compared to seed treatment with $R h i$ zobium@200 g/kg seeds + 100 \% RDF + FYM@ 5 t/ ha $(14,142$ and $1325 \mathrm{~kg} / \mathrm{ha}$, respectively).

Goud et al. (2012) reported that sowing at $90 \times 30 \mathrm{~cm}$ with application of 30:60:30:20:15 kg N: $\mathrm{P}_{2} \mathrm{O}_{5}: \mathrm{K}_{2} \mathrm{O}$ :
S: $\mathrm{ZnSO}_{4} /$ ha obtained higher number of pods/plant (180 cm, 4.6 and 163 , respectively) as compared to sowing at $75 \times 25 \mathrm{~cm}$ with application of 20:45:20:20:15 kg N: $\mathrm{P}_{2} \mathrm{O}_{5}: \quad \mathrm{K}_{2} \mathrm{O}: \quad \mathrm{S}: \mathrm{ZnSO}_{4} /$ ha recorded lower values $(175 \mathrm{~cm}, 4.5$ and 138 , respectively) in pigeon pea. Meena et al. (2012) found that application of fertilizer (60:60:40 NPK kg/ha) at soil-test based recommended rates produced $1.44 \mathrm{t} / \mathrm{ha}$ of grain yield of pigeon pea which was significantly higher as compared to unfertilized control (0.94 t/ha). Singh and Singh (2012) carried out a field study on pigeon pea reported that application of phosphorus 75 $\mathrm{kg} /$ ha produced highest grain, stalk, biological yield and harvest index which was significantly superior to $25 \mathrm{~kg} \mathrm{P} \mathrm{O}_{5} /$ ha and control but remained at par with 50 $\mathrm{kg} \mathrm{P}_{2} \mathrm{O}_{5} /$ ha. Saritha et al. (2012) found that highest seed yield of pigeon pea was recorded in $150 \% \mathrm{RDF}+$ vermicompost@1 t/ha which was comparable with 200\% RDF + vermicompost @ 2 t/ha). Gangaiah et al. (2013) conducted two years field study on pigeon pea during kharif, results revealed that higher plant height, pods/plant 1000-seed weight, seeds/pod, seed yield, biological yield and harvest index were recorded with the application of RDF (recommended dose fertilizers $\mathrm{N} 20$ and P $26.4 \mathrm{~kg} / \mathrm{ha}$ ) over the rest of the treatments. Umesh and Shankar (2013) carried out a field experiment at Bangalore on pigeon pea, results revealed significant increase in pods/plant, test weight, grain (1759 kg/ha) and stalk yield (6004 kg/ha) with application of N:P:K:S:ZnSO 4 @ 50:100:75:10:12.5 $\mathrm{kg} / \mathrm{ha}$ as compared to other treatments. Pandey et al. (2013) reported that application of FYM @ 5.0 t/ha or vermicompost@2.5 t/ha with $100 \%$ RDF proved equally effective for enhancing the grain yield of pigeon pea and both produced significantly higher grain yield than RDF alone. From Varanasi Kumawat et al. (2013b) observed that higher pods/plant and 1000 -seed weight was recorded in the treatment of $100 \% \mathrm{RDF}+50 \% \mathrm{RDN}+5 \mathrm{~kg} \mathrm{Zn} / \mathrm{ha}$ which was statistically similar with $50 \% \mathrm{RDF}+100 \% \mathrm{RDN}+5$ $\mathrm{kg} \mathrm{Zn/ha} \mathrm{and} \mathrm{significantly} \mathrm{superior} \mathrm{to} \mathrm{rest} \mathrm{of} \mathrm{the} \mathrm{treat-}$ ments. Kumawat et al. (2013a) reported that significantly higher yield attributes viz., weight of pods/plant (122.22 and $115.78 \mathrm{~g}$ ), no. of seeds/pod (3.34 and 3.3) seed yield/plant (125.6 and $120.0 \mathrm{~g}$ ) seed yield (2.4 and $1.7 \mathrm{t} / \mathrm{ha})$ and pigeon pea equivalent yield (2.7 and $1.9 \mathrm{q} / \mathrm{ha})$ and land equivalent ratio (1.6 and 1.5$)$ were found the application of $100 \% \mathrm{RDF}+$ $50 \% \mathrm{RDN}+5 \mathrm{~kg} \mathrm{Zn} \mathrm{ha/ha}$ and this treatment was found at par with $50 \% \mathrm{RDF}+100 \% \mathrm{RDN}+5 \mathrm{~kg} \mathrm{Zn} /$ ha during 2008-09 and 2009-2010.

From Shamli (UP) Singh et al. (2014) reported that higher yield attributes viz., pods/plant, pod weight/ plant, grains weight/plant, 1000-grain weight and yields viz., seed, stover and biological yield and harvest index were recorded with the application of 90 $\mathrm{P}_{2} \mathrm{O}_{5} /$ ha but it was statistically comparable with $60 \mathrm{~kg}$ 
$\mathrm{P}_{2} \mathrm{O}_{5} /$ ha and significantly superior to control and $30 \mathrm{~kg}$ $\mathrm{P}_{2} \mathrm{O}_{5} /$ ha. Zadode et al. (2014) field experiment was conducted on PKV-TARA pigeon pea at Akola, results reveals that fertilizer level of 25:50:20:20 kg NPKS/ha significantly increased the grain yield $(25.70 \mathrm{q} / \mathrm{ha})$ and harvest index $(32.23 \%)$ than fertilizer level of 12.5:25:10:10 kg NPKS/ha. Similarly in regard to stover yield did not shown significant difference. Aher et al. (2015) conducted a field study on pigeon pea and reported that yield attributes viz., number of pods/ plant, weight of pods and weight of seeds/plant and yields (seed, stover and biological yield) were increased due to application of $100 \mathrm{~kg} \mathrm{P}_{2} \mathrm{O}_{5} /$ ha but it was at par with 50 and $75 \mathrm{~kg} \mathrm{P}_{2} \mathrm{O}_{5} /$ ha and significantly higher than $25 \mathrm{~kg} \mathrm{P}_{2} \mathrm{O}_{5} /$ ha. From Varanasi (UP) Sahay et al. (2015) reported that no. of pods/plant test weight, grain yield stalk yield and harvest index of pigeon pea significantly increased with the application of $100 \%$ $\mathrm{RDF}+5 \mathrm{t} \mathrm{FYM}+$ Rhizobium + PSB and it was at par with 50\% RDF + 5 t FYM + Rhizobium + PSB.

While working on pigeon pea Rathod et al. (2016) reported that application of $\mathrm{ZnSO}_{4} @ 15 \mathrm{~kg} / \mathrm{ha}$ along with RDF gave higher no. of pods/plant, pod weight/ plant seed weight/plant 100 -seed weight and grain yield of pigeon pea however, it was statistically similar with $\mathrm{RDF}+\mathrm{ZnSO}_{4} 25 \mathrm{~kg} / \mathrm{ha}$. Pal et al. (2016) working on pigeon pea found that yield attributes such as no. of pods/plant, no. of grain/pod weight of pods/plant, grain weight/plant and test weight and grain yield (1831.8 $\mathrm{kg} / \mathrm{ha})$ and stalk yield $(8221.6 \mathrm{~kg} / \mathrm{ha})$ over the remaining treatments. Singh et al. (2016a) observed that among the RDF (recommended dose of fertilizer) levels application of 200\% RDF (30:60:30:30 kg NPKS/ha) gave higher yield attributes like that no. of pods/plant, no. of seeds/pod, 100-seed weight, grain yield and stover yield of pigeon pea but it was statistically similar to $150 \% \mathrm{RDF}$ and significantly superior to $100 \%$ RDF.

Effect of integrated nutrient application on nutrient content and uptake

Singh et al. (1988) observed that application of 10 and $20 \mathrm{~kg} \mathrm{ZnSO} /$ ha significantly increased the $\mathrm{Zn}$ content and uptake by seed of pigeon pea. Kene et al. (1990) conducted an experiment at Nagpur and recorded that application of $37.5 \mathrm{~kg} \mathrm{~N}+75 \mathrm{~kg} \mathrm{P}_{2} \mathrm{O}_{5}+20 \mathrm{~kg} \mathrm{~K} 2 \mathrm{O}+$ $10 \mathrm{~kg} \mathrm{ZnSO} /$ ha significantly improve the $\mathrm{N}, \mathrm{P}$ and $\mathrm{K}$ content in grain and stalk of pigeon pea over control. Srivastava and Srivastava (1993) reported that sulphur had a significant effect on uptake of sulphur by pigeon pea. Rao and Reddy (1997) reported that uptake of P increased upto $60 \mathrm{~kg} / \mathrm{ha}$ and protein content also increased with increasing $\mathrm{P}$ rates. Kantwa et al. (2005) reported that the phosphorus uptake by pigeon pea sole and pigeon pea + urdbean intercropping system was significantly more in $40 \mathrm{~kg} \mathrm{P}_{2} \mathrm{O}_{5} /$ ha over unfertilized crop. Ramesh et al. (2006) conducted a field experiment at Bhopal applying different organic manures (cattle dung $4 \mathrm{t} / \mathrm{ha}$, vermicompost $3 \mathrm{t} / \mathrm{ha}$ and poultry manure $2 \mathrm{t} / \mathrm{ha}$ ) to pigeon pea and reported that the highest protein content in seed was recorded with the application of cattle dung $(21.25 \%)$ followed by vermicompost $(20.90 \%)$ and poultry manure (20.87\%). Singh (2007) observed that application of $50 \% \mathrm{RDF}+5 \mathrm{t} \mathrm{FYM/hato}$ pigeon pea significantly recorded higher uptake of $\mathrm{N}$ (150 kg/ha), P (31.9 kg/ha) and K (98.7 kg/ha) and remained at par with $10 \mathrm{t} \mathrm{FYM/ha}$ and $100 \% \mathrm{RDF}$ treatment. While working on pigeon pea at Junagadh (Gujarat), Patil and Padmani (2007c) observed that $100 \% \mathrm{RDF}\left(25 \mathrm{~N}: 50 \mathrm{P}_{2} \mathrm{O}_{5}: \mathrm{K}_{2} \mathrm{O} 0 \mathrm{~kg} / \mathrm{ha}\right)$ caused significant increase $\mathrm{N}, \mathrm{P}$, and $\mathrm{K}$ content in grain and stalk of pigeon pea, highest protein content and protein yield over the $50 \%$ RDF and control, whereas, it was at par with 75\% RDF. From New Dehli, Kumar and Rana (2007) reported that application of $40 \mathrm{~kg} \mathrm{P}_{2} \mathrm{O}_{5}+25 \mathrm{~kg}$ $\mathrm{S}+\mathrm{PSB}$ significantly improved the $\mathrm{P}$ and $\mathrm{S}$ uptake by pigeon pea over control and $40 \mathrm{P}_{2} \mathrm{O}_{5} /$ ha, however, it was remained at par with $40 \mathrm{~kg}_{2} \mathrm{O}_{5}+25 \mathrm{~kg} \mathrm{~S} / \mathrm{ha}$. Kumawat et al. (2012) carried out a field study for two years on pigeon pea reported that application of $100 \%$ $\mathrm{RDF}+50 \% \mathrm{RDN}+5 \mathrm{~kg} \mathrm{Zn} / \mathrm{ha}$ significantly increased CEC of roots (68.73 and $66.14 \mathrm{meq} 100 \mathrm{~g} /$ dry roots), root $\mathrm{N}$ content (3.03 and $2.80 \%$ ) protein content (21.31 and $21.11 \%$ ) and protein harvest $(\mathrm{kg} / \mathrm{ha})$ (534.49 and $364.01 \mathrm{~kg} / \mathrm{ha}$ ) which was at par with $50 \% \mathrm{RDF}+$ $100 \% \mathrm{RDN}+5 \mathrm{~kg} \mathrm{Zn} / \mathrm{ha}$ and significantly superior to rest of the integrated nutrient treatments during both the years of study. Gangaiah et al. (2013) reported that significantly $\mathrm{N}$ and $\mathrm{P}$ content in grain and their uptake improved with the application of RDF (N 20 and P $26.4 \mathrm{~kg} / \mathrm{ha}$ ), whereas the $\mathrm{Fe}$ and $\mathrm{Zn}$ content in grain was higher noted with the application of RDF through FYM. Umesh and Shankar (2013) observed that application of $\mathrm{N}: \mathrm{P}: \mathrm{K}: \mathrm{S}: \mathrm{ZnSO}_{4}$ @ 50:100:75:10:12.5 $\mathrm{kg} / \mathrm{ha}$ significantly improved the NPK uptake by pigeon pea over rest of the nutrient levels. Working on pigeon pea Zadode et al. (2014) observed that application of 25:50:20:20 kg NPKS/ha significantly improved the N, P, K and S uptake by crop which was superior over 12.5:25:10:10 kg NPKS/ha.

Aher et al. (2015) reported that quality protein content $(20.52 \%)$ was improved significantly by the application of higher levels of phosphorus @ $100 \mathrm{~kg}$ $\mathrm{P}_{2} \mathrm{O}_{5} /$ ha which was at par with 50 and $75 \mathrm{~kg} \mathrm{P}_{2} \mathrm{O}_{5} /$ ha than $25 \mathrm{~kg} \mathrm{P}_{2} \mathrm{O}_{5} /$ ha. Sahay et al. (2015) observed that $\mathrm{N}, \mathrm{P}, \mathrm{K}$ content in grain and stalk were improve significantly with the fertilized plot of $100 \% \mathrm{RDF}+5 \mathrm{t}$ FYM + Rhizobium + PSB and this treatment was on par with $50 \% \mathrm{RDF}+5 \mathrm{t}$ FYM + Rhizobium + PSB in respect to above parameters. Similarly, application of $100 \%$ RDF + 5 t FYM + Rhizobium + PSB also improved significantly the protein content in grain and stalk of pigeon pea. However this treatment was statistically at par with $50 \% \mathrm{RDF}+5$ t FYM + 
Rhizobium + PSB. Singh et al. (2016b) while working on pigeon pea reported that improved $\mathrm{N}, \mathrm{P}, \mathrm{K}$ and $\mathrm{S}$ uptake by grain as well as stover increased with the increasing level of RDF $200 \%$ but it was at par with $150 \%$ and significantly higher over $100 \%$ RDF.

Effect of integrated nutrient application on economics Kumar and Ahlawat (1986) found that application of $50 \mathrm{~kg} \mathrm{~N} / \mathrm{ha}$ to pigeon pea significantly increased the pigeon pea equivalent yield and net return over the 0 and $25 \mathrm{~kg} \mathrm{~N} / \mathrm{ha}$. Billore et al. (1991) conducted a field trail on pigeon pea intercropped with soybean and reported that in case of sulphur application, the improvement in net return was upto $40 \mathrm{~kg} \mathrm{~S} / \mathrm{ha}$. Gupta and Rathore (1995) found that the maximum pigeon pea equivalent yield, gross returns and net returns were recorded with application full dose of RDF to both components over remaining RDF doses. Yadav et al. (1997) reported that pigeon pea equivalent yield and benefit : cost ratio higher were recorded in the pigeon pea + sesame $(100 \%$ RF) than the soybean and clusterbean intercropping systems. Namedo and Gupta (1999) observed that maximum net return was obtained with $100 \%$ RDF $\left(20 \mathrm{~N}\right.$ and $\left.50 \mathrm{P}_{2} \mathrm{O}_{5} \mathrm{~kg} / \mathrm{ha}\right)+$ Rhizobium + PSB followed by $100 \%$ RDF + Rhizobium and 100\% RDF + PSB. Shivran et al. (2000) reported the maximum net return of Rs 22,675 from the cropping systems when pigeon pea was fertilized with $60 \mathrm{~kg}$ $\mathrm{P}_{2} \mathrm{O}_{5}$ /ha. Kumar and Rana (2007) found that application of $40 \mathrm{~kg} \mathrm{P}_{2} \mathrm{O}_{5}+25 \mathrm{~kg} \mathrm{~S} / \mathrm{ha}+\mathrm{PSB}$ significantly higher net return and $\mathrm{B}: \mathrm{C}$ ratio over 40 $\mathrm{P}_{2} \mathrm{O}_{5} /$ ha and control, which was at par with $40 \mathrm{~kg} \mathrm{P}_{2} \mathrm{O}_{5}$ $+25 \mathrm{~kg} \mathrm{~S} / \mathrm{ha}$. Patil and Padmani (2007b) reported that application of $100 \%$ RDF $\left(25 \mathrm{~N}+50 \mathrm{P}_{2} \mathrm{O}_{5}+\mathrm{K}_{2} \mathrm{O} 0.0\right.$ $\mathrm{kg} / \mathrm{ha}$ ) gave the highest net returns, however, the highest net ICBR was obtained with $75 \%$ RDF over $50 \%$ RDF and control. Singh (2007) reported that net returns of pigeon pea were observed with the application of $50 \% \mathrm{RDF}+5 \mathrm{t} \mathrm{FYM/ha}$ over other treatments. In a study Pandey and Kushwaha (2009) reported that combined seed inoculation with Rhizobium + PSB plus 100\% RDF recorded significantly higher net returns (Rs. 38,233/ha) followed by Rhizobium + PSB inoculation with $50 \%$ RDF (Rs. 32,437/ha) of pigeon pea.

Sharma et al. (2010b) from Karnataka reported that application of $100 \% \mathrm{RDF}+15 \mathrm{~kg} \mathrm{ZnSO}_{4} / \mathrm{ha}$ significantly gave maximum gross return, net return and B:C ratio over control. Sharma et al. (2010a) reported that pigeon pea + green gram intercropping system with RDF $+2 \%$ urea spray at 15 and 30 days after harvest of intercrops recorded significantly higher pigeon pea equivalent yield (19.53 and $18.99 \mathrm{q} / \mathrm{ha})$, gross returns (Rs. 31,439 and 30,576/ha), net returns (Rs. 23,984 and 22,928/ha) and B: C ratio (3.81 and 3.63 , respectively) over other intercropping systems. Tiwari et al. (2011) observed that pigeon pea + urdbean cropping with the application of PSB + FYM (a) $2.5 \mathrm{t} / \mathrm{ha}$ recorded higher net returns (Rs. 27,911/ha) and $\mathrm{B}: \mathrm{C}$ ratio (1.58) compared to pigeon pea + maize cropping system (Rs. 14,293/ha) with the B:C ratio of 0.70. Meena et al. (2012) revealed that adoption of induced defoliation in pigeon pea along with NPK + FYM gave the highest system productivity whereas significantly higher net returns (Rs. 32,400/ha) was found under NPK + induced defoliation over the other treatments. Vishwanatha et al. (2012) observed that maximum gross returns (Rs. 80,302 and Rs. 77,448/ ha), net returns (Rs. 62,308 and 59,718/ha) and B:C ratio (3.46 and 3.37) were noted with the application of $100 \%$ RDF to pigeon pea $+100 \%$ RDPK and $50 \%$ $\mathrm{RDN}$ to sunflower as basal $+50 \% \mathrm{RDN}$ as top dress at 45 DAS to sunflower based on population followed by $100 \%$ RDF to pigeon pea and $100 \%$ RDF to sunflower as basal dose based on population, respectively. Sharma et al. (2012) reported that 100 \% RDF, FYM@ 5 t/ ha and Rhizobium + PSB + PGPR gave significantly higher net returns, of Rs. 27,608, 29,764, and 27,330/ ha, respectively. Similar, results were obtained in case of B:C ratio (1.49, 1.59 and 1.52, respectively). Gangaiah et al. (2013) observed that maximum gross return, net return and $\mathrm{B}: \mathrm{C}$ ratio were recorded in $\mathrm{RDF}(\mathrm{N}$ 20 and $\mathrm{P} 26.4 \mathrm{~kg} / \mathrm{ha}$ ) over the rest of the treatments. Umesh and Shankar (2013) reported that application of

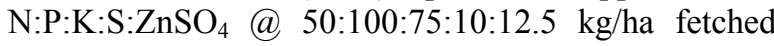
maximum net return and $\mathrm{B}: \mathrm{C}$ ratio as compared to rest of the nutrient levels. Kumawat et al. (2015) working on pigeon pea revealed that maximum gross return $\left(130.74 \times 10^{3} \mathrm{Rs} / \mathrm{ha}\right)$, net return $\left(109.28 \times 10^{3} \mathrm{Rs} / \mathrm{ha}\right)$, $\mathrm{B}: \mathrm{C}$ ratio $(5.11)$, production efficiency $(8.90 \mathrm{~kg} / \mathrm{ha} /$ day) and economic efficiency (401.07 Rs./ha/day) were observed under $100 \% \mathrm{RDF}+50 \% \mathrm{RDN}+5 \mathrm{~kg}$ $\mathrm{Zn} / \mathrm{ha}$ and it was found similar with $50 \% \mathrm{RDF}+100 \%$ $\mathrm{RDN}+5 \mathrm{~kg} \mathrm{Zn/ha}$. Rathod et al. (2016) reported that application of $15 \mathrm{~kg} \mathrm{ZnSO}_{4} /$ ha along with $\mathrm{RDF}$ gave maximum gross return, net return and $\mathrm{B}: \mathrm{C}$ ratio which was statistically at par with $\mathrm{RDF}+\mathrm{ZnSO}_{4}$ $25 \mathrm{~kg} / \mathrm{ha}$. Singh et al. (2016a) working on pigeon pea found that maximum gross return and net return was recorded in $200 \% \mathrm{RDF}$ and it was at par with $150 \%$ RDF and significantly superior to $100 \%$ RDF.

\section{Effect of integrated nutrient application on soil fertility}

Srinivasan and Ahlawat (1984) found that available P in sandy loam soil significantly improved by application of $90 \mathrm{~kg} \mathrm{P} \mathrm{O}_{5} /$ ha over the lower levels of phosphorus $(0,30$ and $60 \mathrm{~kg} / \mathrm{ha})$, while $\mathrm{N}$ and $\mathrm{K}$ remained unaffected. Singh and Faroda (1986) observed that total $\mathrm{N}$, available $\mathrm{N}$ and $\mathrm{P}$ status of soil increased with the application of 40 and $80 \mathrm{~kg} \mathrm{P}_{2} \mathrm{O}_{5} /$ ha in pigeon pea. Application of FYM alone or in combination with chemical fertilizers significantly increased the residual status of available nitrogen and phosphorus in soil (Dudhat et al. 1997). Ramesh et al. (2006) found significantly higher organic carbon $(0.63 \%)$ due to application of $4 \mathrm{t} / \mathrm{ha}$ cattle dung manure $(0.63 \%)$ as 
compared to either chemical fertilizer $(0.54 \%)$ or unfertilized control $(0.50 \%)$. Higher values of available $\mathrm{N}(178.7 \mathrm{~kg} / \mathrm{ha})$ and $\mathrm{K}(578.7 \mathrm{~kg} / \mathrm{ha})$ in soil were also observed in the plots manured with cattle dung than the control. Deshbhratar et al. (2010) reported that application of $20 \mathrm{~kg} \mathrm{~S} / \mathrm{ha}$ (through elemental sulphur) significantly improved the available $\mathrm{N}, \mathrm{P}$ and $\mathrm{K}$ over control. Whereas, maximum sulphur content $(9.52 \mathrm{mg} / \mathrm{kg})$ was recorded with the application of $50 \mathrm{~kg} \mathrm{~S} / \mathrm{ha}$. On other hand the application of $75 \mathrm{~kg}$ $\mathrm{P}_{2} \mathrm{O}_{5} /$ ha (through DAP) significantly improved available soil N, P and S over control. However, the maximum potassium was found in control. Dubey and Vyas (2010) reported that application of $50 \% \mathrm{RDF}+$ FYM@ 5 t/ha + bio-fertilizers proved conducive to sustain the soil health by enhancing the organic carbon, available nutrient status by both crop (pigeon pea and soybean) by reducing the bulk density of soil. Reddy et al. (2011) reported that application of 50\% RDF through inorganic fertilizer + seed treatment with Rhizobium culture and PSB improves nutrient status of soil.

Saritha et al. (2012) observed that among the nutrient levels, significantly higher available N $(201.90 \mathrm{~kg} / \mathrm{ha})$ and $\mathrm{P}_{2} \mathrm{O}_{5}(29.78 \mathrm{~kg} / \mathrm{ha})$ was recorded in the fertilized plot $150 \% \mathrm{RDF}+$ vermicompost @ 1 t $/$ ha as compared to $200 \% \mathrm{RDF}+$ vermicompost @ $2 \mathrm{t} / \mathrm{ha}$ ) but $\mathrm{K}_{2} \mathrm{O}$ did not show any significant differences. Meena et al. (2012) reported that the soil-test based NPK resulted in conjunctive use of fertilizer NPK and FYM improved soil health as revealed by lower bulk density and higher water holding capacity over sole fertilizer treatment. Singh and Singh (2012) reported that application of $75 \mathrm{~kg} \quad \mathrm{P}_{2} \mathrm{O}_{5} / \mathrm{ha}$ gave higher total nitrogen, phosphorus, potassium and sulphur uptake and was significantly superior over $25 \mathrm{~kg} \mathrm{P}_{2} \mathrm{O}_{5} / \mathrm{ha}$ and control. Gangaiah et al. (2013) found that application of RDF through FYM gave higher values of organic carbon, available $\mathrm{N}$ and $\mathrm{P}$ in soil, whereas the higher values of available $\mathrm{K}$ was in RDF thorough vermicompost and lowest in control. Pandey et al. (2013) reported that pigeon pea + urdbean intercropping system with application of FYM @ 5.0 t/ ha or vermicompost @2.5 t/ha and RDF improved bulk density, organic carbon and increased available $\mathrm{N}, \mathrm{P}$ and $\mathrm{K}$ content of the soil over initial soil value. Zadode et al. (2014) reported that significantly higher available $\mathrm{N}, \mathrm{P}, \mathrm{K}$ and $\mathrm{S}$ in soil were noted with the application of 25:50:20:20 kg NPKS/ha as compared to $12.5: 25: 10: 10 \mathrm{~kg} \mathrm{NPKS} / \mathrm{ha}$. Nagar et al. (2016) carried out field study on pigepnpea reported that among combined use of organic manure, application of FYM + phosphocompost and pigeon pea stalk + phosphocompost resulted in improvement of physical, chemical and biological properties of soil over recommended dose of fertilizer (RDF) application. Kumawat et al. (2015) reported that after harvest of crop of pigeon pea significantly improve the organic carbon, available $\mathrm{N}, \mathrm{P}, \mathrm{K}, \mathrm{S}$ and $\mathrm{Zn}$ due to application of $100 \% \mathrm{RDF}+50 \% \mathrm{RDN}+5 \mathrm{~kg} \mathrm{Zn} / \mathrm{ha}$. From Ranchi Singh et al. (2016b) reported that application of $200 \%$ RDF improved the organic carbon, available N, P, K and $\mathrm{S}$ in soil after harvest of crop but it was at par with $150 \%$ and significantly higher over $100 \%$ RDF.

\section{Conclusion}

Good agronomic practices (GAP) and their different components shown potential to excel under change climate condition, there is need to adopt the all the component of advocated technology as a unit not to choose few of them at will, which were leading to several complication soil health hazards and poor response of technology. The using of high yielding varieties with optimum application of nutrient either organic or inorganic sources to pigeon pea increases the production, productivity, profitability and also improved the soil health which is manner of sustainable agro-ecosystem.

\section{REFERENCES}

Adhikary, S. and Sarkar, B.K. (2000). Pigeon pea (Cajanus cajan) intercropping with legumes in Bihar plateau at different level of phosphate. Indian J. Agron., 45 (2): 279-283.

Aher, S.H., Gokhale, D.N., Kadam, S.R. and Karanjikar, P.N. (2015). Effect of sources and levels of phosphorus on yield, quality and phosphorus uptake in pigeon pea. Intern. J. Agric. Sci., 11 (1): 59-62.

Ali, S. (1981). Effect of row spacing and phosphors levels of arhar production under dryland conditions. Indian $J$. Agron., 26 (3): 346-348.

Arunachalam, L., Purushothaman, S., Palaniappan, S.P. and Devasahayam, M.M. (1996). Response of pigeon pea to phosphorus and sulphur nutrition. Madras Agric. J., 82 (4): 266-267.

Billore, S.D., Upadhyaya, M.S. and Yadav, S. (1991). Response of soybean and pigeon pea intercropping to phosphorus and sulphur under rainfed conditions. Res. Develop. Rep., 8 (2): 133-136.

Chauhan, R.S. and Singh, K.B. (1981). Response of pigeon pea varieties to levels of phosphorus and row spacing under rainfed conditions. Indian J. Agron., 26 (1): 4952.

Dekaj and Pal, M. (1995). Bioenergetics of different sole and pigeon pea (Cajanus cajan) based intercropping systems. Indian J. Agric. Sci., 65 (9) : 639-643.

Deshbhratar, P.B., Singh, P.K., Jambhulkar, A.P. and Ramteke, D.S. (2010). Effect of sulphur and phosphorus on yield, quality and nutrients status of pigeon pea (Cajanus cajan L. Millsp.). J. Environ. Bio., 31 (6): 933 $-937$.

Dubey, S. and Yyas, M.D. (2010) Integrated nutrient management in pigeon pea + soybean intercropping system under rainfed conditions. Mysore J. Agric. Sci., 44 (4): 781-785.

Dudhat, M.S., Mathukia, K. and Khampara, V. B. (1997). Effect of nutrient management through organic and inorganic source on growth, yield, quality and nutrient 
uptake by wheat (Triticum aestivum). Indian J. Agron., 42 (3): 455-458.

Gangaiah, B., Ahlawat, I.P.S., Shivakumar, B.G. and Babu, M.B.B.P. (2013). Impact of organic mode of production on performance of pigeon pea (Cajanus cajan L.) during conversion from conventional to organic production. Indian J. Dryland Agric. Res. Dev., 28(2): 27-31.

Ghosh, P.K., Mohanty, M., Bandyopadhyay, K.K., Painuli, D.K. and Misra, A.K. (2006). Growth, competition, yield advantage and economics in soybean/pigeon pea intercropping system in semi-arid tropics of India. Field Crop Res., 96: 90-97.

Goud, V.V., Konde, H.B. and Mothod, P.V. (2012). Optimization of agronomic requirement for medium duration pigeon pea hybrid under rainfed condition in vertisol. Legume Res., 35 (3): 264-267.

Gupta, I.N. and Rathore, S.S. (1995). Effect of fertility in pigeon pea (Cajanus cajan) plus sesame (Sesamum indicum) intercropping system under rainfed conditions. Indian J. Agron., 40 (3): 390-393.

Jat, H.S. and Ahlawat, I.P.S. Response of pigeon pea (Cajanus cajan) + groundnut (Arachis hypogea) intercropping system to planting and phosphorus management. Indian J. Agron., 48 (3): 156-159.

Kantwa, S.R., Ahlawat, I.P.S. and Gangaiah, B. (2005). Effect of land configuration, post-monsoon irrigation and phosphorus on performance of sole and intercropped pigeon pea. Indian J. Agron., 50: 278-280.

Karwasra, R.S. and Kumar, A.K. (2007). Response of pigeon pea (Cajanus cajan L.) to NPK in Haryana. Haryana J. Agron., 23 (1\&2): 117

Kene, D.R., Sirsat, M.T., Thakare, K.K. and Darange, O.G. (1990). Response of pigeon pea to higher level of fertilization and its effect on nodulation and nitrogen fixation. PKV Res. J., $14: 182-185$.

Kumar, A. and Ahlawat, I.P.S. (1986). Effect of planting geometry and nitrogen fertilization in pigeon pea based intercropping systems. Indian J. Agron., 31 (1): 112114.

Kumar, A. and Kushwaha, H.S. (2006). Response of pigeon pea (Cajanus cajan) to sources and levels of phosphorus under rainfed condition. Indian J. Agron., 51 (1): 60-62.

Kumar, A. and Rana, K.S. (2007). Performance of pigeon pea (Cajanus cajan) + greengram (Phaseolus radiatus) intercropping system as influenced by moisture conservation practices and fertility level under rainfed conditions. Indian J. Agron., 52: 31-35.

Kumar, A. and Rana, K.S. (2007). Performance of pigeon pea (Cajanus cajan) + greengram (Phaseolus radiatus) intercropping system as influenced by moisture conservation practices and fertility level under rainfed conditions. Indian J. Agron., 52 (1): 31-35.

Kumawat, N., Singh, R.P. and Kumar R. (2013b). Productivity, economics and water use efficiency of rainfed pigeon pea + black gram intercropping as influenced by integrated nutrient management. Indian J. Soil Cons., 41: $170-176$

Kumawat, N., Singh, R.P., Kumar, R. and Hari, Om. (2013a). Effect of integrated nutrient management on the performance of sole and intercropped pigeon pea (Cajanus cajan) under rainfed conditions. Indian $\mathrm{J}$. Agron., 58: 309-315.
Kumawat, N., Singh, R.P., Kumar, R., Kumari, A. and Kumar, P. (2012). Response of intercropping and integrated nutrition on production potential and profitability on rainfed pigeon pea. J. Agric Sci., 4: 154162.

Kumawat, N., Singh, R.P., Kumar, R., Yadav, T.P. and Hari, Om. (2015). Effect of integrated nutrient management on productivity, nutrient uptake and economics of rainfed pigeon pea (Cajanus cajan) and blackgram (Vigna mungo) intercropping system. Indian J. Agric. Sci., 85: 171-176.

Meena, M.C., Dwivedi, B.S., Singh, D., Sharma, B.M., Kumar, K. and Rana, D.S. (2012). Effect of integrated nutrient management on productivity and soil health in pigeon pea (Cajanus cajan)-wheat (Triticum aestivum) cropping system. Indian J. Agron., 57 (4): 333-337.

Nagar, R.K., Goud, V.V., Kumar, R. and Kumar, R. (2016). Effect of organic manures and crop residue management on physical, chemical and biological properties of soil under pigeon pea based intercropping system. Intern. $J$. Farm Sci., 6: 101-113.

Namedo, S.L. and Gupta, S.C. (1999). Efficacy of biofertilizers with different levels of chemical fertilizer on pigeon pea (Cajanus cajan). Crop Res., 18 (1): 29-33.

Padmalatha, Y. and Rao, G. (1993). Dry matter accumulation and its partitioning of winter pigeon pea (Cajanus $\mathrm{ca}$ $j a n)$ as affected by varieties, plant densities and fertility levels. Indian J. Agron., 38(4): 665-667.

Pal, A.K., Singh, R.S., Shukla, U.N. and Singh, S. (2016). Growth and production potential of pigeon pea (Cajanus cajan L.) as influenced by intercropping and integrated nutrient management. J. Appl. Natu. Sci., 8: $179-183$

Pandey, I. B., Singh, S.K. and Tiwari, S. (2013). Integrated nutrient management for sustaining the productivity of pigeon pea (Cajanus cajana) based intercropping systems under rainfed condition. Indian J. Agron., 58 (2): 192-197.

Pandey, R. and Kushwaha, H.S. (2009). Productivity and profitability of pigeon pea under different sources of nutrients in rain fed condition of central. Indian. J. Food Leg., 22 (4): 304-305.

Patil, A.B. and Padmani, D.R. (2007a). Effect of integrated nutrient management on growth and yield of pigeon pea (Cajanus cajan L. Millsp.). Intern. J. Agric. Sci., 3 (2): 49-51.

Patil, A.B. and Padmani, D.R. (2007b). Effect of IPM practices on yield, quality and economic of pigeon pea (Cajanus cajan L. Millsp.) under rainfed conditions. Intern J. Agric. Sci., 3 (2): 202-204.

Patil, A.B. and Padmani, D.R. (2007c). Nutrient uptake pattern of pigeon pea (Cajanus cajan) as influenced by integrated nutrient management. Intern. J. Agric. Sci., 3 (2) : 176-178

Ramesh, P., Singh, M., Panwar, N.R., Singh, A.B. and Ramana, S. (2006). Response of pigeon pea (Cajanus cajan) varieties to organic manures and their influence on fertility and enzyme activity of soil. Indian J. Agric. Sci., 76 (4): 252-254.

Rao, B.S. and Reddy, T.M.M. (1997). Effect of plant populations and phosphorus levels on growth and dry matter production of hybrid pigeon pea ICPH-8 (Cajanus cajan L.). J. Res.-ANGRAU., 24 (1-2) : 142- 
143.

Rathod, P.S., Dodamani, B.M. and Patil, D. (2016). Effect of micronutrients on growth and productivity of pigeon pea under rainfed conditions. Res. Environ. Life Sci., 9 (6) $748-750$.

Reddy, A.S.R., Babu, R., Reddy, M.C.S., Khan, M.M. and Rao, M.M. (2011). Integrated nutrient management in pigeon pea (Cajanus cajana). Intern. J. Applied Bio. Pharm. Tech., 2 (2): 476-470.

Reddy, M.M., Padmaja, B., Malathi, S. and Rao, L.J. (2007). Effect of micronutrients on growth and yield of pigeon pea. J. SAT Agric. Res., 5 (1): 1-3.

Sahay, A., Pratap, T., Ttyagi, S., Nanher, A.H., Singh, R. and Shekher, S.S. and Singh, V.P. (2015). Effect of integrated nutrient management on growth, yield and quality of pigeon pea (Cajanas cajan L. Millsp.) cv. Pusa 9. The Bioscan, 11 (1): 293-296.

Saritha, K.S., Pujari, B.T., Basavarajappa, R., Naik, M.K., Rameshbabu, Desai, B.K. (2012). Growth of pigeon pea [Cajanus cajan (L.) Millsp.] and nutrient status of soil after the harvest of crop as influenced by plant densities, different irrigation and nutrient levels. Karnataka J. Agric. Sci., 25 (1): 134-136.

Saxena, H.S., Mandal and Chandel, A.S. (2001). Effect of inorganic and organic sources of nutrients on soybean [Glycine max (L.) Merril], Indian J. Agron., 44 (1): 135140.

Sharma, A., Nakul, H.T., Jelgeri, B.R. and Surwenshi, A. (2010b). Effect of micronutrients on growth, yield and yield components in pigeon pea (Cajanus cajan L. Millsp.). Res. J. Agric. Sci., 1 (2): 142-144.

Sharma, A., Pandit, S.R. and Mohan, C. (2010a). Integrated nutrient management in pigeon pea (Cajanus cajan) based intercropping system under rain fed conditions. Karnataka J. Agric. Sci., 23 (4): 584-589.

Sharma, A., Rathod, P.S., Dharmaraj, P.S. and Chavan, M. (2012). Response of pigeon pea to biofertilizers in pigeon pea based intercropping systems under rainfed conditions. Karnataka J. Agric. Sci., 25: 322-325.

Shivran, P.L. and Ahlawat, I.P.S. (2000). Effect of cropping systems and fertilizers on pigeon pea (Cajanus cajan) and wheat (Triticum aestivum) in pigeon pea-wheat sequence. Indian J. Agron., 45: 669-676.

Shivran, P.L., Ahlawat, I.P.S. and Shivran, D.R. (2000). Effect of phosphors and sulphur on pigeon pea-wheat cropping sequence. Indian J. Agron., 45 (1) : 25-30.

Singh, A.K. and Singh, R.S. (2012). Effect of phosphorus levels and bioinoculants on growth and yield of long duration pigeon pea [Cajanus cajan (L.) Millsp]. J. Food Leg., 25(1): 73-75.

Singh, P.K., Kumar S., Kumar, A. and Kumar, S. (2014). Effect of phosphorus and sulphur fertilization on growth, yield, nutrient uptake, their recovery and use efficiency by pigeon pea [Cajanus cajan (L.) Millsp] genotypes. Asian J. Biol. Life Sci., 3 (1): 70-76.

Singh, R.C. and Faroda, A.S. (1986). Effect of cropping system and phosphorus on nodulation in pigeon pea and soil fertility. Indian J. Agron., 31 (2): 203-204.

Singh, R.S. 2007. Effect of organic and inorganic sources of nutrition on productivity of long duration pigeon pea (Cajanus cajan (L.) Millsp). Environ. Ecol., $25 \mathrm{~S}$ (Special 3A) : 768-770

Singh, S.K., Kumari, N., Karmakar, S., Puran, A.N. and
Pankaj, S.C. (2016b). Productivity, economics and nutrient uptake of hybrid pigeon pea as influenced by different fertility and lime levels under rainfed conditions. Environ. Ecol., 34 (2A): 726-729.

Singh, S.K., Kumari, N., Singh, C.S., Karmakar, S. and Puran, A.N. (2016a). Performance of hybrid pigeon pea (Cajanus cajan L.) as influenced by nutrient and lime levels under rainfed condition of Jharkhand. The Bioscan, 11 (1): 227-330.

Singh, T. and Pal, M. (2003). Growth parameters, yield attributes and yield of pigeon pea as influenced by cropping systems and nitrogen + phosphorus levels. Ann. Agric. Res., 24 (4) : 755-759.

Singh, Y., Gaur, N.S., Singh, D. and Singh, D. (1997). Response of pigeon pea (Cajanus cajan) to NPK in western part of Uttar Pradesh. Ann. Agric. Res., 15 (4) : 495-495.

Srinivas, A. and Raju, M.S. (1997). Phosphorus fertilization of short duration pigeon pea verities in Alfisoles under rainfed conditions. Leg. Res., 20 (2) : 104-108.

Srinivasan, A. and Ahlawat, I.P.S. (1984). Studies on planting pattern and phosphate fertilization of sole and mixed stand of pigeon pea. Indian J. Agron., 29: 249253.

Srivastava, G.P. and Srivastava, V.C. (1993). Response of rainfed pigeon pea (Cajanus cajan L.) to phosphorus and sulphur in acid red-loam soil. Indian J. Agric. Sci., 63 (1): 43-443.

Thakur, H.S., Raghuwanshi, R.K.S., Verma, R.S. and Verma, G.P. (1988). Effect of fertilizer doses and plant density on yield pigeon pea. Adv. Crop Moni. Environ. Progress in Ecol., 10: 373-377.

Tiwari, A.K. (2016). Pulses in India: Retrospect and Prospect, Govt. of India, Ministry of Agri. \& Farmers Welfare, Directorate of Pulses Development, Vindhychal Bhavan, Bhopap, MP.

Tiwari, D., Sharma, B.B. and Singh, V.K. (2011). Effect of integrated nutrient management in pigeon pea based intercropping system. J. Food. Legu., 24 (4): 304-305.

Umesh, M.R. and Shankar, M.A. (2013). Yield performance and profitability of pigeon pea (Cajanus cajan L.) varieties under different nutrient supply levels in dryland alfisols of Karnataka. Indian J. Dryland Agric. Res. Dev., 28(1): 63-69.

Velayutham, A., Kalpana, R. and Sankaran, N. (2003). Effect of fertility levels on pigeon pea and greengram intercropping systems. Madras Agric. J., 90 (10-12): 607-610.

Verma, C.B., Lallu and Yadav, R.S. (2004). Effect of boron and zinc application on growth and yield of pigeon pea. Indian J. Pulses Res., 17 (2) : 149-151.

Vishwanatha, S., Anilkumar, S.N., Koppalkar, B.G., Pujari B.T. and Desai, B.K. (2012). Effect of fertilizer management on economics and yield advantages of pigeon pea and sunflower intercropping system. Intern. J. Fore. Crop Imp., 3: 76-79.

Yadav, R.P., Sharma, R.K. and Shrivastava, U.K. (1997). Fertility management in pigeon pea (Cajanus cajan) based intercropping system under rainfed conditions. Indian J. Agron., 42 (1): 46-49.

Zadode, R.S., Sethi, H.N. and Vilhekar, S.C. (2014). Response of pigeon pea to organic and inorganic fertilization. Adv. Res. J. Crop Imp., 5 (2): 181-184. 